\title{
Roles of Educational Planners in the Promotion of In-service Teachers' Education for Primary School Teachers in Nigeria
}

Ileuma Senimetu (Ph.D) $)^{1^{*}}$, Yusuf Akinjide Isaac ${ }^{1}$

${ }^{1}$ Lead City University, Ibadan, Oyo State

\author{
Article History \\ Received: 08.12.2021 \\ Accepted: 14.01.2022 \\ Published: 27.01.2022 \\ Journal homepage: \\ https://www.easpublisher.com
}

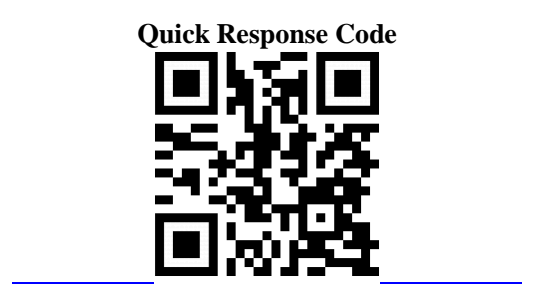

Abstract: The present paper examined the roles of educational planners in the promotion of in-service teachers' education for primary school teachers in Nigeria. Primary school education happens to be the foundation and bedrock for all other levels of education in any nation and therefore teachers at the primary school education must be thoroughly equipped, trained and qualified. The major means by which teachers can be equipped and trained is teachers' education. Teachers' education is in three phases- pre-service, induction and in-service teachers' education. In-service teachers education which is carried out via conferences, seminars, workshops, exhibitions, regular and correspondence courses at various teachers' institutions is aimed at improving the expertise, effectiveness and quality of serving teachers. It is also referred to as continuous education for teachers already in service. This is done to keep them updated and current in the teaching profession. Educational planners who are those that play a major role in the planning of all levels of education also play roles in in-service teachers' education. However, the roles they play and how they carry it out could determine the promotion of inservice teachers' education for primary school teachers in Nigeria. In this paper, conclusion and recommendations were given.

Keywords: Educational Planners, In-service Teachers' Education, Primary School.

Copyright () 2022 The Author(s): This is an open-access article distributed under the terms of the Creative Commons Attribution 4.0 International License (CC BY-NC 4.0) which permits unrestricted use, distribution, and reproduction in any medium for non-commercial use provided the original author and source are credited.

\section{INTRODUCTION}

The progress of any educational system greatly depends on planning. Planning is the act of examining the future and creating appropriate actions for achieving specified goals and objectives. Educational planning thus involves the setting of educational goals and objectives, formulation of educational policies and coordination of educational programmes and activities that would lead to the accomplishment of the set goals and objectives. It further involves financial planning and budgeting as well as human resource planning (Akpan, 2015). Educational planning which is usually carried out by educational planners is the process of applying rational and systematic analysis to educational development with the major aim of ensuring that education is more effective and efficient in responding to the needs, goals and desires of students and society at large (Coombs, 1970: 14). Educational planning can be carried out for all aspect of teachers' education including pre-service and in-service teachers' education.

In-service teachers' education can be defined as relevant courses and activities in which a teacher in service (that is, a serving teacher) may participate to upgrade his or her professional knowledge, skills, and competence in the teaching profession. It therefore encompasses all forms of education and training given to a teacher who is already on the job of teaching and learning. Furthermore, in-service teachers' education is designed for the manpower development of all levels of education including the primary school system. If teachers are to perform their functions effectively and efficiently, it becomes imperative for them to need training in new skills and modern methodology. In fact, the higher the level of educational attainment by teachers, the higher the level of educational standard in the country (Osamwonyi, 2016). No wonder the National Policy on Education (2014) asserted that no level of education can rise above the quality of its teachers. To meet the growing needs of education including primary education in a global economy, it becomes necessary that educational planners play their role in promoting in-service teachers' education so as to provide sound in-service education for teachers to update their skills, knowledge and experience (Osamwonyi, 2016).

\section{Meaning of Teacher Education}

Teacher education is a programme that is related to the professional development of teacher proficiency and skill that will enable, empower and 
make the teacher to meet the requirements of the profession and face the challenges therein (Lal, 2016; Rani, 2017). Goods Dictionary of Education in Kumar and Azad (2016) explains that teacher education means all the formal and non-formal activities and experiences that help to qualify a person to assume and discharge his or her responsibilities as a member of the educational profession more effectively. The National Council for Teacher Education in Lal (2016) has defined teacher education as - A programme of education, research and training of persons to teach from pre-primary to higher education level.

Teacher education includes teaching skills, sound pedagogical theory and professional skills. Teaching skills has to do with providing training and practice in different techniques, approaches and strategies that would help the teachers to plan and impart instruction, provide appropriate reinforcement and conduct effective assessment. Pedagogical theory has to do with the philosophical, sociological and psychological considerations that would enable the teachers to have a sound basis for practicing the teaching skills in the classroom while professional skills include the techniques, strategies and approaches that would help teachers to grow in the profession and also work towards the growth of the profession (Lal, 2016; Pradhan, 2016).

\section{In-Service Teachers' Education}

According to the International Encyclopedia of Teaching and Teacher education (1987), teacher education can be considered in three phases: preservice, induction and in-service (Dunking, 1987). According to Billing (1976), in-service education is serving teachers' development which is a deliberate and continuous process involving the identification and discussion of present and anticipated needs of individual teachers for furthering their job satisfaction and career prospects and of the educational institution for supporting its academic work and plans, and also implementation of programmes of the teachers' activities designed for the harmonious satisfaction of these needs.

In-service education is also referred to as continuing education that is designed for the retraining, re-skilling and updating the knowledge of teachers who are the manpower in the school system (Osamwonyi, 2016). In-service teacher education broadly performs the following functions:

i. initiates and orients teachers to new roles and technologies and

ii. upgrades serving teachers in tasks with which they are currently occupied;

iii. updates teachers in issues concerning content, methodology and evaluation and

iv. Provides opportunities for unqualified or under qualified on-the-job teachers to update and upgrade their knowledge (Mohanty and Pradhan, 2013).

According to National Policy on Education (FRN, 2004), the goals of Teacher Education are to:

1. encourage further the spirit of enquiry and creativity in teachers;

2. help teachers to fit into social life of the community and the society at large and enhance their commitment to national goals;

3. produce highly motivated, conscientious and efficient classroom teachers for all levels of our educational system;

4. enhance teacher's commitment to the teaching profession and

5. Provide teachers with the intellectual and professional background adequate for their assignment and make them adaptable to changing situations.

Kpangbam (1992) pointed out that the rationale for In-service teachers' education for teachers are as follows:

i. It is recognized that however good existing preservice teacher education programmes are, they by their very nature cannot equip intending teachers with all they require for a life-time of work in the classroom;

ii. there is growing expectation that teacher should reform their own practice, as it is only then that meaningful curriculum development could take place in the daily routine of classrooms;

iii. there are clear indications that teachers are members of an under-educated profession, whose working conditions do not encourage the kinds of peer interaction which would improve performance;

iv. there is increasing awareness of the impact of social, political and technological changes and of the need for teachers to be conscious of and responsive to such changes and

v. there is a growing number of specialized administrative roles that teachers have to take up with passing years in teaching, for example, head of department, head of blocks and counsellor and effective performance of the tasks requires specialized training because they involve the exercise of leadership skills and judgement of a high order

vi. trends in teaching patterns and methods are constantly changing and it therefore becomes imperative that teachers are updated with the current teaching methods (Bolam, 1978; Willson, 1977).

According to Bramley (1991), in-service education is the systematic development of attitudes, knowledge, skills, and behavior patterns required by teachers to perform adequately at their given task or job. It is globally practiced with the belief that it fosters professional development of teachers. Specifically, in- 
service education and training has been adopted to promote continuous improvement of teaching staff, eliminate differences within the background preparation of teachers, keep the teaching profession abreast of new knowledge, enable realization of creative innovations and facilitate teachers to tackle responsibilities and challenges associated with the changing learning environment (Osamwonyi, 2016; Sheth, 2004).

In practice, in-service teacher training is recognized as a necessary part of the overall process of teacher education, which can be achieved via attending events such as lectures, films, exhibitions, seminars, conferences and workshops in which practical solutions to trending difficulties are introduced and materials required for implementing these solutions are produced (Alkuş and Olgan, 2014; Osamwonyi, 2016). According to Asaya (1991), there are eight varieties of in-service education:

a) Conferences (give participants an opportunity to question others and discuss ideas presented);

b) Institutes (a series of lectures designed to give participants as much information as possible in a short time, usually two or three days);

c) Staff meetings (may perform a useful in-service function but generally used to acquaint teachers with administrative proceeds users and policies);

d) Workshops (usually a moderate size group, where each person has a problem to solve that is closely related to his field);

e) Committee (five or several members work on a problem that could be impossible for a whole staff to tackle);

f) Professional reading (with the aid of a professional library' study groups);

g) Individual conferences (dependent of feelings of mutual understanding and support existing between teacher and supervisor) and

h) Visits and demonstrations (opportunity to observe actual teaching techniques).

The above varieties of in-service education also provide platforms through which teachers are introduced to new developments and teaching materials to help them in their work, such as new curricular, new methods and innovations, and specific equipment (Nzarirwehi and Atuhumuze, 2019). The vital need of in-service education is for improving the efficiency and professional growth of teachers. Teachers by means of in-service education revive their theoretical knowledge, refresh their experiences, develop a wider outlook and acquire new information and therefore re-orients themselves. In the absence of such refreshing opportunity, teachers could relapse into professional illiteracy and fall into the old set of mindset and pattern of doing things (Mohanty and Pradhan, 2013).

\section{In-Service Teachers' Education for Primary Education in Nigeria \\ According to Eneasotor (1997) teacher} education is a form of education, which is specially geared or tailored towards the production of people who will teach, essentially in the primary, secondary schools and tertiary institutions. Teacher education therefore is that aspect of formal education, which prepares people to become qualified and competent teachers, ranging from Teacher's Grade Two certificate to Doctorate degree in education. It involves the production of teachers for all the levels of education especially the primary school system which is the bedrock and foundation of all other levels of education (Nasiru, 2011). In-service teachers' education has therefore been defined to include all those educational and training activities in which primary school teachers engage in following their initial professional training and certification and which is intended mainly to improve their professional knowledge, competencies, behaviours and attitudes in order that they can teach more effectively (Mohanty and Pradhan, 2013).

Yadav and Bhardwaj (2013) stated that confidence instilled by in-service teacher education facilitates planning and preparation towards effective teaching in primary schools. These skills lead to the building of a human resource pool that is dedicated and committed to teaching and positively influencing the overall delivery in the education system. If teachers' education is given high priority by Nigeria government, then enhancing the instructional delivery of primary school teachers through in-service education in form of re-training, workshops, seminars, conferences and resource fellows etc., would be achieved (Olorunsola, 2014).

\section{Roles of Educational Planners in the Promotion of In-Service Teachers' Education for Primary School Teachers in Nigeria}

Primary school education is at the base of educational system and therefore constitutes the foundation or bedrock of the nation's new technological and scientific education. The need for enhancing inservice training needs of primary school teachers cannot be over-emphasized or under-estimated. A teacher who is not constantly expanding and deepening his knowledge cannot do an adequate job as a primary school teacher (Isichei, 1997 in Olorunsola, 2014). In a study of in-service teacher training in Nigeria, Amadi (2013) notes that although in-service training has been embraced to counter the inadequacies of pre-service training, it still fails to adequately prepare teachers for the continued changes in teaching techniques and materials. There is therefore need for educational planners to perform their roles in order to promote inservice teachers' education, ensure the challenges facing in-service teachers' education are remedied and quality of teachers is produced especially for primary school 
education which is the foundation of education in the nation.

Planning is so important that scholarship on inservice teacher training has found that effectiveness of in-service teachers' education can only be achieved with proper planning and implementation (Zaslow, 2014). Authors also stated that for in-service training to be effective, "backward planning" must be emphasized to ensure that in-service training exactly matches teacher and learner needs and addresses the intended objectives (Bayar, 2014; Guskey, 2014). There is need to have a well-planned in-service education programme with clearly defined objectives growth and improvement of instruction and leadership skills (Osamwonyi, 2016).

When In-service teachers' education is planned, the effectiveness of teachers collectively or individually is enhanced in response to new knowledge, new ideas and changing circumstances in order to improve, directly or indirectly the quality of pupils' education (Zulkifli and Omar, 2014). Educational planners therefore have huge roles to play in the promotion of in-service teachers' education. One of such role is ensuring that proper interpretation and implementation of syllables used in teachers' education and instilling dedication of trainers to duty so as to bring about right teaching and good quality of teachers produced (Nasiru, 2011). Planners are to ensure that instructional delivery personnel should possess certain minimum levels of competence in their chosen fields so that the graduates of such teachers' programmes are properly taught and endowed with appropriate skills for the labour market (Joshua, 1997; Taiwo, 1980).

According to Ejima (2012), in-service education which could be in form of conferences, seminars and workshops is often practiced for serving teachers but is not uncommon to find directors and other senior officials of the ministry and relevant departments enrolling for the conference at the expense of the practicing teachers. Enrolments of artisans, motor cycle riders and traders for such programmes are also common scenes in Nigeria. Of course, reasons for this may not be farfetched as it is most likely for financial gains and not for professional development (OsarenrenOsaghae and Irabor, 2018). Another role of educational planners is thus ensuring that in-service teachers are those that partake in the education and that the programme is not hijacked by others especially those bottlenecks in the ministry of education.

A critical issue in in-service teachers' education is the curriculum for professional development of teachers. Teachers' education is carried out in several educational institutions with differing cultures, knowledge, beliefs, ideals and attitudes which reflect in the curriculum. Educational planners should therefore make sure that there is uniformity in inservice teachers' education curriculum, course content and methodology in order to ensure that similar ideals and knowledge is passed on to several serving teachers in various educational institutions in the nation as this would ensure that all teachers transmit to the primary school pupils the right beliefs, attitudes and ideals of the society (Osarenren-Osaghae and Irabor, 2018; Ejima, 2012; Lawal, 2003). Educational planners are to make sure quality assurance mechanisms is practiced in which case the serving teachers strive to meet the standards and so the professional development is enhanced (Osarenren-Osaghae and Irabor, 2018; Osarenren-Osaghae, 2014).

Akinwumi (2009) stated that conventional teaching procedures are the major mode of curriculum delivery of teacher education in Nigeria. Effort in providing appropriate solution as regards this requires adequate proper planning on equipping institutions, their academic staff and non-tutorial personnel for effective use of ICT for continuous improvement of teacher education. Educational planners' role is to make sure that the National Certificate of Examination and other teachers' education bodies' curriculum for the training of primary school teachers should be constantly reviewed in five year cycle or less and the review should be a continuous process. It should be possible to begin with first principles of what teachers need to know and be able to do to meet the demands of teaching and learning. All primary school teachers should be trained as multi grade teachers, able to teach the core subjects across the curriculum. However, this is not sufficed to say that there would be no area to specialization in their subject areas.

Planners of education are to ensure that teachers' education climate is positive and conducive to collaboration in matters pertaining to teachers' development. The absence of a supportive work context can create difficulties for teacher development and change-based initiatives (Zulkifli and Omar, 2014). Lee (2005) and Heaney (2004) posited that educational planners are to be committed to finding out and identifying the training needs for teachers and prepare a suitable training based on their needs. Educational planners get feedback and make evaluation based on program objectives so as to ensure achievement of the in-service training for teacher (Zulkifli and Omar, 2014). Their role also include ensuring that effective education programs for in-service teacher professional development are designed and the goals are clearly defined.

According to Maduabum (1992), there are different forms of in-service education which include: regular courses, conferences, workshops, seminars, correspondence courses and exhibitions. Educational planners' roles include the planning of teachers' education in such a way that serving teachers are able to attend the different forms of education, are not stressed attending it and syllabus is covered without "mad rush" 
so as to make sure the quality of the teachers is not in doubt. Available activities for participants should be thoroughly planned in a way that they are personal and related to the job settings in the classroom. Furthermore, educational planners should ensure that the size of the teachers participating in the education is not too large so as to allow for meaningful instruction. Lecturers should take only courses they can teach and not overload themselves. Such overloading causes timetabling problems resulting in ineffectiveness in teachers' education (Osamwonyi, 2016).

\section{CONCLUSION}

It can therefore be concluded that the roles of educational planners when carefully carried out can promote or determine in-service teachers' education for effectiveness of primary school teachers in Nigeria. This is to say that when educational planners fulfill their roles in in-service teachers' education, it results to the equipping of teachers who become qualified primary school teachers in the nation.

\section{RECOMMENDATIONS}

This paper therefore recommends the following:

1. The roles of educational planners in in-service teachers' education should be strictly carried out to ensure production of quality and effective teachers for the primary school level.

2. Facilities for effective teachers' education should be provided

3. Only qualified lecturers should be allowed to teach and train in-service teachers to yield optimum results

4. Teachers should be supported or sponsored to take part in in-service teachers' education so as to encourage greater participation as it seems most teachers are self-sponsored

\section{REFERENCES}

- Akinwumi, F.S. (2009). Management of teacher education in Nigeria: issues, problems and remedies. A lecture note in Department of Educational Management, University of Ibadan, Ibadan, Nigeria. 1-14. Available at: https://www.researchgate.net/publication/23761633 2

- Akpan, C. P. (2015). Educational planning in Nigeria: a historical perspective. A lecture note at University of Calabar, Nigeria. 1-19. Available at: https://www.researchgate.net/publication/33877063 8

- Alkuş, S., \& Olgan, R. (2014). Pre-service and inservice preschool teachers' views regarding creativity in early childhood education. Early Child Development and Care, 184(12), 1902-1919. https://doi.org/10.1080/03004430.2014.893236

- Amadi, N. M. (2013). In-service training and professional development of teachers in Nigeria: through open and distance education. Bulgarian
Comparative Education Society, Paper presented at the Annual Meeting of the Bulgarian Comparative Education Society (11th, Plovdiv, Bulgaria, May 14-17, 2013). Retrieved from http://files.eric.ed.gov/fulltext/ED567172.pdf

- Asaya, S. A. (1991). In-service education of teachers: problems and prospects. A paper presented at the first biennial conference on teacher education organized by the Lagos State College of Education. Otoljanikin, 10th-14th February.

- Bayar, A. (2014). The components of effective professional development activities in terms of teachers' perspective. International Online Journal of Educational Sciences, 6(2), 319-327. https://doi.org/10.15345/iojes.2014.02.006

- Bolam, R. (1978). Innovations in the in-service education and training of teachers, Paris; OECD.

- Bramley, P. (1991). Evaluating training effectiveness: translating theory into practice. New York, NY: McGraw-Hill Book Company.

- Dunking, M.J. (1987). The International Encyclopedia of Teaching and Teacher Education. Oxford, Pergamum Press.

- Ejima, O.S. (2012). Teachers' professional development in the 21 st century Nigeria: The journal, the potholes and the patches. Global Voice Educational, 1(1), 3-4.

- Federal Republic of Nigeria. (2014). National policy on education revised (4th edition) Abuja, NERDC Press

- Guskey, T. R. (2014). Planning professional learning. Educational, School, and Counseling Psychology Faculty Publications, 15. Retrieved from https://uknowledge.uky.edu/edp_facpub/15

- Heaney, L. (2004). Leading professional development: a case study. The international Journal of Educational Management, 18(1), 37-48

- Isichei. (1997). Gender education and socioeconomic growth in nigeria. In Ejiogu (ed) Emergent issues in Nigeria Education.

- Joshua, M. T. (1997). Teacher evaluation: meaning, importance, historical development and purposes. Nigerian Education Journal, 2, 135-142.

- Kumar, P., \& Azad, S. (2016). Teacher education in India: some policy issues and challenges. IJARIIE, 2(6), 1217-1224. ISSN (O)-2395-4396

- Lal, D. (2016). A journey of teacher education. International Journal of Peace, Education and Development, 4(1), 9-17. DOI: 10.5958/24549525.2016.00002.0

- Lawal, H.S. (2003). Teacher education and professional growth of the 21st century Nigeria teacher. In African Symposium: An On-Line African Educational Research Journal, 3(2), 1-10

- Lee, H.L. (2005). Developing a professional development programme model based on teachers needs. The Professional Educator, 27(1\&2), 29-49

- Maduabum, M. A. (1992). Issues in in-service education of science teachers in Nigeria in Afe, J. 
O. (eds) In-service education of teachers: the Nigerian experience, Asaba, JID Printers (Nig.) Ltd

- Mohanty, S.P., \& Pradhan, N. (2013). In-Service teacher education for qualitative improvement of elementary teachers: A perspective framework. International Journal of Academic Research Reflector, 2(1), 17-23.

- Nasiru, A.B. (2011). Teacher education challenges and prospects in innovation in Nigeria educational system. Knowledge Review, 22(2), 129-132.

- Nzarirwehi, J., \& Atuhumuze, F. (2019). In-Service teacher training and professional development of primary school teachers in Uganda. IAFOR Journal of Education, 7(1), 19-36.

- Olorunsola, E.O. (2014). Enhancing the instructional delivery of primary school teachers through in-service training in Nigeria. Literacy Information and Computer Education Journal (LICEJ), 3(1), 1738-1742.

- Osamwonyi, E.F. (2016). In-Service education of teachers: overview, problems and the way forward. Journal of Education and Practice, 7(26), 83-87. ISSN 2222-1735 (Paper) ISSN 2222-288X (Online)

- Osarenren-Osagahe, R.I. (2014). Influence of accreditation on quality assurance: an experiential report on the Nigerian public universities. International Journal of Cross-Disciplinary Subjects Education, 5(2), 1626-1631

- Osarenren-Osaghae, R. I., \& Irabor, Q. O. (2018). Educational policies and programmes implementations: A case study of education funding, universal basic education (UBE) and teacher education. International Journal of
Educational Administration and Policy Studies, 10(8), 91-102. DOI: 10.5897/IJEAPS2016.0457

- Pradhan, P. (2016). Modalities of teacher education in India. International Journal of Peace, Education and Development, 4(1), 31-39. DOI: 10.5958/24549525.2016.00005.6

- Rani, A. (2017). Problems and solution of teacher education. Inter. J. Acad. Res. Educ. Rev. 5(1), 1519. DOI: $10.14662 /$ IJARER2017.002

- Sheth, S. (2004). Knowledge for teacher development in India: The importance of local knowledge for in-service education. International Journal of Education Development, 24, 39-52. https://doi.org/10.1016/j.ijedudev.2003.09.003

- Taiwo, C. S. (1980). The Nigerian education system. Past, present and future. Lagos Thomas Nelson (Nig) Ltd. 3-7.

- Wilson, S. (1977). Current trends in staff development in Rubin, L. Curriculum handbook, London, Allyn \& Bawn Inc. 2-9

- Yadav, B., \& Bhardwaj, P. (2013). Impact of inservice teacher education programmes on class room transactions. Educationia Confab, 2(6), 8-16.

- Zaslow, M. (2014). General features of effective professional development. In $\mathrm{T}$. Woods, $\mathrm{H}$. Ginsburg, \& M. Hyson (Eds.). Preparing early childhood educators to teach math (pp. 97-115). Baltimore: Brookes Publishing.

- Zulkifli, C.M., \& Omar, C. (2014). The Need for in-service training for teachers and its effectiveness in school. International Journal for Innovation Education and Research, 2(11), 1-9.

Cite This Article: Ileuma Senimetu \& Yusuf Akinjide Isaac (2022). Roles of Educational Planners in the Promotion of In-service Teachers' Education for Primary School Teachers in Nigeria. East African Scholars J Edu Humanit Lit, 5(1), 22-27. 